\title{
Obituary
}

\section{In memory of Johan van Rekom (1963-2015)}

Tim Oliver Brexendorf

Joachim Kernstock

Shaun M. Powell

Journal of Brand Management (2015) 22, 486. doi:10.1057/bm.2015.29

It is with sadness and a profound sense of loss, that we note the passing of Dr Johan van Rekom, a member of the editorial board of the Journal of Brand Management.

Johan was Assistant Professor in RSM at Erasmus University, Rotterdam, where his $\mathrm{PhD}$ on Corporate Identity was also awarded. He was an advocate for interdisciplinary research and investigated organisational identity and its effects on the motivation of organisational members, as well as the role brand essence plays in positioning and repositioning of brands. His published work includes several papers within the Journal of Brand Management (see for example, van Rekom et al, 2006; van Rekom et al, 2013).
Johan was an inspirational, engaging and popular scholar with wide-ranging knowledge and interests. He had a humble, generous and nurturing nature, plus a great sense of humour and will be sorely missed.

\section{REFERENCES}

van Rekom, J., Jacobs, G., Verlegh, P.W.J. and Podnar, K (2006) Capturing the essence of a corporate brand personality: A Western brand in Eastern Europe. Journal of Brand Management 14 (1/2): 114-124.

van Rekom, J., Berens, G. and van Helderen, M (2013) Corporate social responsibility: Playing to win, or playing not to lose? Doing good by increasing the social benefits of a company's core activities. Journal of Brand Management 20(9): 800-814. 